\title{
Alcoholic hepatitis and liver transplantation: the good news and what to do about it
}

\section{Giovanni Addolorato*}

Institute of Internal Medicine, Catholic University of Rome, Rome, Italy

*Correspondence: g.addolorato@rm.unicatt.it

\section{A commentary on}

Early liver transplantation for severe alcoholic hepatitis

by Mathurin, P., Moreno, C., Samuel, D., Dumortier, J., Salleron, J., Durand, F., Castel, H., Duhamel, A., Pageaux, G. P., Leroy, V., Dharancy, S., Louvet, A., Boleslawski, E., Lucidi, V., Gustot, T., Francoz, C., Letoublon, C., Castaing, D., Belghiti, J., Donckier, V., Pruvot, F. R., and Duclos-Vallée, J. C. (2011). N. Engl. J. Med. 365, 1790-1800.

A recent French trial in the New England Journal of Medicine (Mathurin et al., 2011) reported that early orthotopic liver transplantation (OLTx) improves survival in patients with a first episode of severe alcoholic hepatitis $(\mathrm{AH})$ not responding to medical therapy. In this trial, 26 patients with severe $\mathrm{AH}$ at high risk of death were selected (i.e., $<2 \%$ of patients admitted for an episode of severe $\mathrm{AH}$ ). The results of this trial are very encouraging as the cumulative 6-month survival rate was higher among patients who received early transplantation than among those who did not $(P<0.001)$. Notably, this benefit of early transplantation was maintained through 2 years of followup $(P=0.004)$.

Alcoholism is still considered by many individuals and clinicians, as a bad habit and there is a general reluctance to transplant alcoholic individuals who still drink. However, research in neuroscience has improved dramatically in the last decades, and we do know by now that alcoholism is a chronic relapsing medical disease of the brain, and not a bad behavior. Let's make a comparison with hepatitis $\mathrm{C}$ virus ( $\mathrm{HCV}$ ). We all know that given the presence of extrahepatic sites of HCV replication, the new transplant liver is infected by HCV in virtually all patients, with a 10 - to 20 -fold increase in levels of viremia after liver transplantation, and progression to HCV-related cirrhosis is estimated to reach $20-30 \%$ at 5-year follow-up (Gruener et al., 2004). No one, however, would deny an OLTx to an HCV-infected patient because of the "risk" of the re-infection after surgery.

As for alcoholic patients, at present, a minimum of 6 months of total alcohol abstinence before OLTx is required to reduce the risk of alcohol recidivism. Notably, in the French trial (Mathurin et al., 2011) not only survival rate was higher in patients receiving early OLTx, but also a very low number of patents $(n=3 ; 11.5 \%)$ relapsed, i.e., one at 720 days, one at 740 days, and one at 1140 days after transplantation (Mathurin et al., 2011). The take home message of this trial is very important and has significant clinical implications. This trial, in fact, clearly suggests the need to re-consider the 6-month rule. Alcoholic patients who receive OLTx might have a better survival rate if the transplant is performed sooner. As such, it is important, at least in selected cases, to consider the possibility to perform the OLTx the soonest possible in alcoholic patients with severe AH. The possibility to re-consider the 6-month rule, however, needs to be discussed by the scientific and clinical community, together with the need to provide more effective monitoring and treatments for alcoholism both before and after the OLTx. As such, there is a crucial need to develop a more integrated approach in the management of these patients, including the need to follow-up these patients by team players coming from different fields (e.g., hepatology, psychiatry, addiction medicine, surgery).

\section{REFERENCES}

Gruener, N. H., Jung, M. C., and Schirren, C. A. (2004). Recurrent hepatitis $\mathrm{C}$ virus infection after liver transplantation: natural course, therapeutic approach and possible mechanisms of viral control. J. Antimicrob. Chemother. 54, 17-20.

Mathurin, P., Moreno, C., Samuel, D., Dumortier, J., Salleron, J., Durand, F., Castel, H., Duhamel, A., Pageaux, G. P., Leroy, V., Dharancy, S., Louvet, A., Boleslawski, E., Lucidi, V., Gustot, T., Francoz, C., Letoublon, C., Castaing, D., Belghiti, J., Donckier, V., Pruvot, F. R., and Duclos-Vallée, J. C. (2011). Early liver transplantation for severe alcoholic hepatitis. $N$. Engl. J. Med. 365, 1790-1800.

Received: 27 December 2011; accepted: 27 December 2011; published online: 10 January 2012.

Citation: Addolorato G (2012) Alcoholic hepatitis and liver transplantation: the good news and what to do about it. Front. Psychiatry 2:80. doi: 10.3389/fpsyt.2011.00080

This article was submitted to Frontiers in Addictive Disorders, a specialty of Frontiers in Psychiatry.

Copyright (C) 2012 Addolorato. This is an open-access article distributed under the terms of the Creative Commons Attribution Non Commercial License, which permits non-commercial use, distribution, and reproduction in other forums, provided the original authors and source are credited. 